\title{
REDES DE RELAÇÕES TIMBIRA: ESTUDOS DE CASO A PARTIR DOS ETNÔNIMOS EM USO PELOS RÀMKÔKAMẼKRA/CANELA E OS GAVIÃOPYHCOP CATIJI
}

\section{TIMBIRA'S RELATIONSHIPS: CASE STUDIES FROM ETHNONYMS CURRENTLY USED BY RÀMKÔKAMẼKRA/ CANELA AND GAVIÃO PYHCOP CATIJI}

\author{
Ligia Raquel Rodrigues Soares* \\ Maycon Melo*
}

\section{Introdução}

Os etnônimos, considerados nas etnografias como termos de autodesignação que se proliferam de acordo com o enunciador, mais do que servir para ordenar as descrições com conotações históricas, criando hierarquizações ou apenas comparando os termos presentes com seus correlatos do passado, "fornecem pistas sobre o modo em que os nativos praticam sua socialidade" (CALÁVIA SÁEZ, 2013, p. 9).
É interessante observar como, nesses casos, "as relações intertribais aparecem como resíduos etnográficos praticamente inexplorados" (DEMARCHI; MORAIS, 2015, p. 8). Já conhecemos alguns desses "resíduos" que antropólogos (as) como Nimuendajú (1946), Damatta (1976), Melatti (1978), Ladeira (1982) e Barata (1981) nos deixaram sobre as relações - principalmente de casamentos e cerimoniais -, que indivíduos de povos Timbira, distintos, mantinham com os Ràmkôkamẽkra/Canela, Krahô, Pyhcop

\footnotetext{
* Doutora em Antropologia Social pela Universidade Federal do Amazonas (UFAM). Bolsista Pós-Doc na Universidade Federal do Tocantins (Palmas/TO/BR) e University of Florida. ligiarrsoares@gmail.com.

** Doutor em Ciências Sociais. Mestre em Antropologia Social. Professor na Universidade CEUMA (São Luis/MA/BR). mayconmelodoc@gmail.com.
} 
catiji, Krĩkati, Apinaje. E se dermos atenção a esse assunto, talvez iremos encontrar muitos outros povos relacionados nessa grade de relações, inclusive com povos não pertencentes ao tronco linguístico Jê. Por isso, no trabalho com os etnônimos podemos ampliar nossa percepção sobre as redes de relação Timbira em constante atualização e transformação.

Este artigo tem como objetivo pensar como se articulam os povos que utilizam para autodefinição tais etnônimos, tratando especialmente dos contextos de uso entre os Ràmkôkamẽkra/Canela ${ }^{1}$ e os Gavião Pyhcop catiji, e como essas redes sugerem formas amplas de socialidade.

\section{Os Timbira}

Com mais de duzentos anos de contato com a sociedade não-indígena, os povos Timbira ocupavam tradicionalmente uma grande extensão de terra situada nos cerrados do norte do antigo Goiás e sul do Maranhão. Essas regiões foram sendo gradativamente ocupadas desde o final do século XVIII, e principalmente a partir do século
XIX, por frentes de penetração oriundas do leste, principalmente do Piauí. 0 "país Timbira”, assim chamado por Nimuendajú (1946), é formado, atualmente, pelos povos indígenas Krahô (TO), Krĩkati (MA), Apànjêkra/ Canela (MA), Ràmkôkamẽkra/Canela (MA), Pyhcop catiji (MA), Krepỳm Catêjê (MA), Krẽnyê, Pàrkatejê/Gavião (PA) - considerados pelo referido autor como Timbira orientais -, e Apinaje (TO) - como Timbira ocidental. Essa classificação, segundo Nimuendajú (1946), levou em consideração as afınidades linguísticas e culturais.

Até o início do século XIX, os povos Timbira resistiram às tentativas de colonização promovidas pelas frentes de expansão. Além de utilizar estratégias de alianças (ainda que por vezes temporárias) com os não-indígenas, também recorreram ao uso das armas diante do avanço dessas frentes de expansão sobre seus territórios. Esse processo resultou na consequente invasão das terras indígenas, na diminuição populacional drástica dos Timbira e na redução crescente da caça disponível para a subsistência desses povos.

1. A escolha por utilizar esses dois etnônimos se deve ao fato de que estes são denominações generalistas, que não privilegiam nenhuma das autodenominações dos povos que ali estão reunidos e que compõem o coletivo Ràmkôkamẽkra/Canela. 


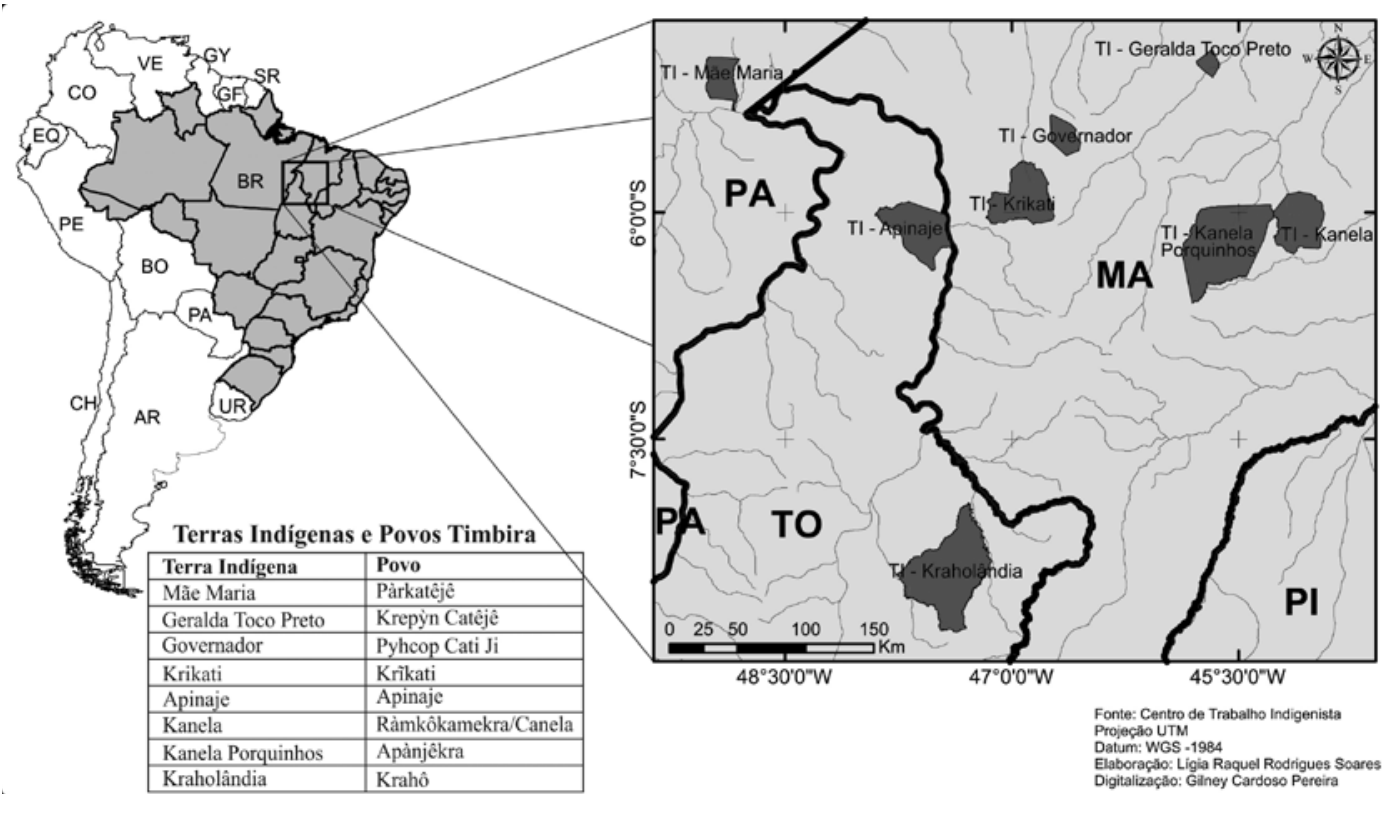

Fonte: Soares, 2015.

Durante o período Imperial, através do sistema de diretorias, também implantado no Maranhão, os Timbira foram reunidos em aldeamentos indígenas. Segundo Siqueira (2006), a implantação desse sistema provocou genocídio e levou alguns grupos ao desaparecimento enquanto unidades étnicas. Mas, ainda de acordo com o mesmo autor, os Timbira também realizaram sua própria política junto aos agentes coloniais, voltada para a sua preservação étnica. Essa política consistia na aliança de grupos Timbira, mesmo havendo o risco de destruição e sujeição a outros grupos.

Segundo Oliveira (2002), esse processo foi considerado em dois momentos. 0 primeiro com a efetivação das "guerras justas" movidas pelas expedições punitivas oficiais e pelas bandeiras realizadas, em conjunto com os moradores locais, contra os Timbira, em geral, e os Canelas e Mateiros, em especial. O segundo momento foi pela inserção desses grupos na legislação e nas ações defınidas no âmbito da política indigenista imperial, implantada nas províncias através do sistema de diretorias e colônias indígenas (2002, p.159).

Especificamente sobre os etnônimos, Nimuendajú foi o primeiro a dar atenção ao caso dos Timbira. Para ele, as terminações kra (cran) e jê(catê) variavam de acordo com o substantivo empregado. "Si um nome tribal é formado em (ka-me-)kra ou em (ka-te-)ye depende unicamente do substantivo empregado. Separar as tribos -kra das -ye ou até querer derivar uns dos outros é, portanto, inteiramente inadmissível" (1944, p. 9). Outro autor, Azanha (1984), dedicou atenção maior ao tema, propondo reflexões que permanecem atuais ao afırmar que os sufixos caté/jê e (ca)mekra não estão submetidos ao substantivo que os 
antecede, como sugeriu Nimuendaju, mas que são formas como os grupos Timbira se denominam e que devem indicar algo a respeito do modo como estes mesmos grupos se relacionam.

Enquanto os que apresentam a forma -catêjê marcam, pela designação, uma diferença quanto a ocupação territorial (de domínio de parte de um mesmo território), a forma -(ca) mekra (me+ indicador de plural) assinala uma diferença na origem e que não remete a um lugar geográfico. A primeira forma sugere uma diferenciação tendo por base uma classificação "totêmica". Portanto, os dois modos de designação dependem, antes de tudo, do modo como se diferenciam uns dos outros os grupos Timbira. (AZANHA, 1984, p.11)

Nessa linha de compreensão, o sufixo -catêjê implica vizinhança e contiguidade à forma, enquanto o sufixo (ca)mekra marca uma diferença quanto à origem. 0 que caracterizaria as relações entre os grupos designados nesta segunda forma seria o estado de guerra permanente entre eles. Não se tem notícia de guerra entre povos que se designavam mutuamente pela forma -catêjê (AZANHA, 1984). A máxima que o estudo de Azanha criou, o modo como os povos Timbira se nomeiam, está ligado ao modo como se relacionam, parece ter eclipsado abordagens de alcance teórico menor, mas que poderiam nos dizer das transformações a que estas formas estão submetidas por estarem sob contornos específicos que a história infringiu a cada uma delas.

Se, entre os povos Timbira temos apenas os trabalhos de Azanha (1984) sobre os sufixos catêjê e (ca)mekra como pedra angular na discussão de etnônimos, talvez a única pedra edificada sobre este tema, desde Nimuendaju, entre os povos da Amazô- nia, sejam os debates sobre etnônimos, que acompanham há muito tempo as pesquisas etnográficas. "Suas dimensões podem ser apreciadas nos artigos do Handbook of South American Indians que chegou a enumerar uma centena de supostos grupos Pano, ou no livro de Alves da Silva (1977) que [...] enumera nada menos que 332 ‘divisões' dos grupos Uaupés” (CALÁVÍA SÁEZ, 2013, p. 6). Esses etnônimos, conjuntos de nomes com termos que designam partes de um grupo, são formados frequentemente pela composição de nomes de animais, plantas e outras qualidades acrescidos de um sufixo que se refere a "gente" ou a "povo".

Calávia Sáez (2013) explica que, durante um longo período, agiu-se como se os etnônimos fossem partes de partes, conjuntos de conjuntos que implicavam filiações históricas duvidosas e uma hierarquização dos nomes desde o passado até o presente. Depois, foram imaginados como parentelas corresidente, como Rivière (1984) ao escrever sobre as Guianas, mas ainda como partes de um aglomerado de regras frouxas, no entanto, sem a hierarquia de lógicas de pertença. 0 descrédito que levou esses dados a se tornarem "ruídos" nas etnografias, uma vez que são lembrados, mas pouco explorados analiticamente, coincidiu com a decisão de tomar os "nomes verdadeiros" como aqueles que um povo usa para designar-se (SAEZ, 2013). Rapidamente proliferou o uso destes etnônimos, multiplicando-se os povos nominados de acordo com os denominadores que os antropólogos/as encontravam durante suas etnografias em uma mesma região. Esses termos de autodesignação,

[...] costumam funcionar, no vernáculo, como pronomes. E os pronomes, por muito que 
a palavra iluda a uma substituição- estão lá em nome do nome - não representam necessariamente um nome; o nome pode simplesmente não existir e os pronomes existem porque agem de modo diferente ao do nome. Sobretudo porque não são essenciais. Pronomes exercem como sujeitos ao igual que os nomes, sem ser, como os nomes, facilmente objetiváveis. (CALÁVIA SÁEZ, 2013, p. 9)

Essa discussão de Calávia Sáez é parte de seu trabalho sobre o uso dos coletivizadores nawa/bo/wo usados para construir etnônimos entre os grupos da família linguística Pano, mas ele aumenta sua área de análise para além do tronco linguístico $\mathrm{Pano}^{2}$, e propõe um rendimento analítico para a etnologia ameríndia, em que os etnônimos seriam também categorias alternativas às de identidade e parentesco. Mais do que servir para ordenar as descrições com conotações históricas, os etnônimos, afirma Calávia (2013, p. 9) "fornecem pistas sobre o modo em que os nativos praticam sua socialidade".

Seguindo essa linha de análise, Barbara Arisi escreveu sobre os etnônimos Pano a partir de pesquisa sobre o contato entre os povos Matis e Korubo na TI Vale do Javari, na Amazônia. 0 recorte étnico colocou famílias diferentes sob o mesmo nome Matis, misturando os etnônimos. Arisi então trata os etnônimos "como un stock de gran flexibilidad y criatividad que los Matis usan para designar a partes de sí mismo o a sí propios, a familias, a residentes en una misma maloca o a pueblos vecinos" (ARISI, 2012, p. 20), pois mesmo com uso restrito, os etnônimos continuam em utili- zação e em transformação. Os etnônimos são usados a partir de um ponto onde os narradores se localizam no "continuum" de "povos isolados" a "povos misturados", sendo mais flexíveis, cambiantes e múltiplos, uma vez que muitos termos dispostos nesse continuum não são excludentes, mas complementares.

No caso dos Ràmkôkamẽkra/Canela, observamos um volume maior de dados sobre o tema dos etnônimos. Nimuendajú (1946), ao tratar dos diferentes povos que os compunham, faz referência ao ritual do Pepcahàc. Em sua etnografia o autor destaca:

At 7 p.m. on June 3 all the men assembled in the plaza and grouped themselves in four divisions. This arrangement, which is peculiar to the King Vulture ceremonial, rests on a distinctive principle, viz., the matrilineal descent of the population according to the tribes that gradually contributed to the present village community. For the Ramkõ'kamekra have come to incorporate fragments of the Ca'kamekra, the Karẽ'kateye, and the Krõ'rekamekra (pp. 30-32, 35). Of the Apa'nyekra only two survivors remain in the village, while the Hõtí (=Apinayé) immigrants are quite extinct, so that these two tribes are no longer represented at the segregation in question. The indigenous and numerically quite preponderant Ramkõ'kamekra occupy the very center, the three surviving immigrant fragments are grouped along the periphery of the plaza according to the direction from which their ancestors migrated. On the evening of June 3 the grouping was apparently tried only tentatively. (NIMUENDAJÚ, 1946, p. 217-218) 
Segundo Crocker (2009, p. 16)

Os Canelas atualmente acreditam que são descendentes de pelo menos cinco diferentes tribos timbiras. Eles ainda celebram esta crença no seu festival que perdura todo o verão e é chamado de Guerreiros Simulados (pep-kahàk: guerreiros- como se fossem). Em um dos atos deste festival, os descendentes masculinos da tribo principal, os Mõltũm-re (indo junto, resistente povo, pequeno), sentam-se no centro do pátio. Os Mõltũm-re são os Ramkokamekra de Nimuendajú. Os homens das tribos que se juntaram aos Ramkokamekra sentam-se nas bordas do pátio, na direção geográfica de onde eles acreditam terem se originado. Estes são os descendentes de povos Lama (Karë Katêyê), Caititu (Krôô-re-khãm-më-khra-re), Piranha (Apaniekra) e Raposa (Tsoo-khâm-më-khra). Os Canelas não têm nome para a totalidade de remanescentes das principais nações que constituem a tribo atual.

Crocker (2009, p. 14) destaca que, por volta do século XVI, os povos Canela viviam em aldeias entre os rios Parnaíba e Tocantins e, embora não se tenham dados exatos sobre a quantidade de povos Timbira que havia, estima-se que existiram entre trinta a cinquenta povos chamados pelos colonizadores portugueses como Timbira, mas que se autodenominavam mẽhhĩ. Esse termo é ainda utilizado como etnônimo por todos os outros povos Timbira, com exceção dos Apinaje que se autodenominam panhĩ.

Antes da fase histórica considerada como de pacificação, os diferentes povos Timbira eram inimigos e lutavam entre si. Haviam aqueles que formavam alianças e negociavam entre si, muito embora as alianças, segundo Crocker, não pudessem ser plenamente confiáveis devido es- pecialmente aos ataques de surpresa que ocorriam, geralmente por vingança ou para manter em baixa o número de inimigos, causando dessa forma uma proliferação de rixas entre as diferentes "nações" Timbira (CROCKER, 2009, p. 15).

Sobre a composição dos atuais Ràmkôkamẽkra/Canela, Oliveira chama atenção sobre como o processo de territorialização, seja através das fronteiras agrícolas ou através das frentes pastoris, dizimou e deu uma nova reconfiguração territorial às várias nações Timbira. Sobre a composição desses povos, Oliveira (2011, p. 94) aponta:

Os antigos Capiekran ou "Canelas finas" e os Sakamekran ou "Timbira Matteiros", de cujo processo de territorialização e amálgama étnico emergiram os atuais Ramkokamekra Canela formavam, durante as primeiras décadas do século XIX, os grupos Timbira de localização mais oriental no Maranhão. Por essa razão, constituíram objeto prioritário da administração colonial portuguesa, interessada na expansão das fazendas agrícolas pelo alto Itapecuru e na ocupação pastoril do território timbira, o que foi precedido pela ação das "tropas de linha" e de "bandeiras".

Já Silva Júnior (2006, p. 13) sobre os etnônimos destaca que:

Os Canela se autodenominam Më mõltum-re (os que sempre estiveram por aqui). E que esses resultam da reunião de outros povos, entre os quais estão: Ràm-kô-kãm -më-kra ou Më mõl-tum-re, Mateiros que também foram chamados de Irom-catêjê (povos da mata), os Xoo-kãm-më-kra (filhos da raposa), Carë-kãm-më-kra (filho do barro vermelho), Apaniekrá (filho da piranha), e Crõõ-re-kãm-më-hkra (filhos do porco queixada). 
Percebemos, ao longo das nossas pesquisas, que os etnônimos apesar de serem sempre abordados de forma muito sucinta pelos etnógrafos que estiveram entre os povos Timbira, nunca foram temas centrais dos trabalhos desenvolvidos até então por esses pesquisadores.

Consideramos, portanto, que a nossa contribuição virá a preencher uma lacuna nos estudos sobre povos Timbira, pois entender essas composições e suas dinâmicas são imprescindíveis para ter uma compreensão interna de como operam entre esses povos que atualmente são denominados e compreendidos como apenas um povo, aqui no caso, os Ràmkôkamẽkra/Canela e os Gavião Pyhcop catiji. Dessa forma, é possível compreender as divisões de aldeias diante dos conflitos, as constantes desavenças internas ao participar das reuniões do pátio, as acusações de feitiçaria, os conflitos por conta dos recursos escassos (cargos e salários de professores, agentes de saúde, entre outros).

\section{Os Ràmkôkamẽkra/Canela ${ }^{3}$ e os etnônimos}

Os diferentes etnônimos aos quais os Ràmkôkamẽkra/Canela fazem referência sempre chamaram muita atenção da coautora desse trabalho. A cada ida a campo a coautora percebia a dinâmica de funcionamento da diversidade ali existente. A trajetória junto aos Ràmkôkamẽkra/Canela levou-a a desenvolver a pesquisa de doutorado sobre o Pep-cahàc - ritual de formação masculina que tem como um dos focos principais a diversidade de povos que vivem na Aldeia Escalvado. A cada momento desse ritual, a composição de povos ficava mais evidente e era de tal intensidade que estremecia as danças e os embates performáticos realizados no ritual do Pep-cahàc.

Como já mencionado, a diversidade de povos que atualmente formam os Ràmkôkamẽkra/Canela é explicitada durante o ritual do Pep-cahàc, chamado por Crocker de "Guerreiros Simulados", momento em que essas diferentes identidades são assumidas e reafirmadas. Em um dos atos desse ritual, os descendentes masculinos do principal povo (Mẽmõltũmre) sentam-se no centro do pátio, enquanto os homens que pertencem aos demais povos, que se juntaram para formar os Ràmkôkamẽkra/Canela, sentam-se nas bordas do pátio, na direção geográfica de onde são oriundos, cada qual com seus líderes, os Tamhàc (chefes honorários).

Durante outro momento do ritual do Pep-cahàc, são encenados ataques aos outros grupos que se encontram na beira externa da rua circular. Nesse ato, chamado de “Apê craw-crawre", é cantada uma cantiga empolgante, com muita gritaria e drama. A cena lembra um embate de guerra. Linhas de inimigos são formadas segurando varas e, no último momento, quando estes estão prestes a se enfrentar, entram em cena os

3. É importante destacar neste texto as diferenças de categorias utilizadas pelos autores. Estes utilizam duas categorias diferentes ao abordar os estudos de caso aqui em destaque.As duas categorias são povos e grupos. A opção por povos para tratar dos Ràmkôkamẽkra/Canela está vinculada a uma opção política percebida durante o trabalho de campo, por conta da autonomia e da especificidade de cada um dos povos que compõem os atuais Ràmkôkamẽkra/Canela, e por considerar que grupo pressupõe uma parte relacionada a um todo, enquanto que povo é um todo em si. Já a categoria grupo, utilizada pelo coautor, pressupõe povos que se reconhecem por etnônimos diferentes, mas que à frente aos "brancos" se dizem todos Gavião Pyhcop catiji. 
dois descendentes dos chefes-de-visitas (krĩ cunẽa mẽ hõ pahhi ou chefes honorários da aldeia) que se inserem desarmados no espaço entre os guerreiros. A alta honraria da posição cerimonial desses dois homens obriga os guerreiros a interromperem os seus ataques. Esse papel cerimonial é uma prerrogativa transmitida de forma patrilinear, havendo duas linhas de descendência deste papel. Ou seja, existem sempre dois desses chefes honorários na aldeia.

Apresenta-se ali, nesse ritual, o respeito à presença dos chefes-de-visitas com seus amigos formais ${ }^{4}$. Nesse momento, cantam bem mais alto, batendo os pés ritmicamente e levantando uma enorme nuvem de poeira. Após toda essa encenação, o canto ali entoado chega ao fim. 0 ato se encerra e a multidão se espalha pela aldeia. A ferocidade encenada nesse ritual é uma demonstração convincente da antiga belicosidade dos Canela. Mas também evidencia o alto valor que os Canela destinam à manutenção da paz interna (CROCKER, 2009, p. 31).

0 povo mais fortalecido naquele momento de reunião dos diferentes povos era o Mẽmoltũmre. Esse processo de reunião com diferentes povos, formando os Ràmkôkamẽkra/Canela, deu-se por diferentes fatores. Como mostra Crocker (2009, p. 27), os Xoo-kãm-mẽ-kra (povo Raposa da Aldeia Mucura) juntaram-se aos Mẽmoltũmre em 1900, em decorrência da diminuição de sua população e por conta da usurpação das suas terras, promovida pelos conquistadores brasileiros; os Carë-kãm-më -kra (povo do Barro vermelho), os Crôô-re -kãm me-hkra (povo filhos do Caititu) e os
Iromcatejê (povo da Mata) juntaram-se por razões similares: perda de espaço territorial no processo de colonização. Para essas reuniões dos povos, ocorreram cerimônias específicas no momento dessa unificação (CROCKER, 2009, p. 27-29), como as performances relacionadas ao que Crocker chamou de "veado cansado", que era o ato de estabelecimento dos chefes-honorários, uma instituição presente entre os Timbira.

0 povo que desejava a paz enviava um guerreiro desarmado agindo como se fosse uma caça ferida. Este, se aceito pelo povo visitado, tornava-se o chefe-honorário do povo visitado entre os visitantes, devendo atuar para defender os interesses desse povo dentro do seu próprio povo de origem. 0 povo visitante também escolhia um dentre os guerreiros do povo visitado, e o elegia como seu chefe-honorário, para defender os interesses dos visitantes dentro do seu povo de origem. Além disso, nestas situações os membros de sexo oposto dos dois povos faziam sexo entre si e promoviam-se casamentos entre os casais dos diferentes povos.

No entanto, após a reunião desses diversos povos em uma única aldeia, as tensões constantes levaram a acusações de feitiçaria entre eles. Esse foi o motivo que ocasionou a execução de um feiticeiro do povo Xoo-kãm-mẽ-kra (Raposa), morto na ausência dos Anciões Raposa no Conselho dos Anciões Canela, episódio que gerou a separação desses povos durante dez anos.

A denominação "Ràmkôkamẽkra" somente é utilizada porque foi o nome que se tornou conhecido a partir de Nimuenda-

4. Constitui-se numa relação de solidariedade e evitação entre duas pessoas. Essa relação se evidencia em momentos liminares ou de prestação de serviços cerimoniais como: momentos de luto, reintrodução da pessoa a vida social, rituais de iniciação e de formação. 
jú. Porém, de acordo com as observações em campo, eles (os Canela) não assumem essa denominação em nenhum momento, a não ser para uso externo. Nem mesmo consideram que exista entre os povos que atualmente os compõem, filhos dos Ràmkôkamẽkra. Os Canela afırmam que continuam a usar tal denominação para se relacionar com os não-indígenas porque "é um nome que está ao vento" e que "todos já os conhecem por esse nome”. Somente por isso continuam a utilizar tal etnônimo. Um outro ponto que observei e que talvez justifique que o nome seja ainda utilizado por eles é pelo fato de não privilegiar nenhum dos povos que ali estão reunidos, o que acaba sendo um nome neutro e possível de ser utilizado, assim como a denominação "Canela".

A reunião de povos que compõem os Ràmkôkamẽkra/Canela se apresenta em diferentes momentos da vida cotidiana. Um deles é através do sistema de parentesco cognato, isto é, reconhece-se terminologicamente o parentesco tanto para o lado paterno quanto materno, evidenciando e reforçando o pertencimento a povos diferenciados. No entanto, a residência pós -matrimonial é, como para a maioria dos Jê, matrilocal ou uxorilocal (MELATTI, 1978; GIRALDIN, 2000). Isso gera nesses povos uma ideologia uterina, devido ao fato das mulheres sempre permanecem nas casas e serem os homens os que circulam pelas outras casas com o casamento. Entre os Ràmkôkamẽkra/Canela, esse é um sistema muito operante.

Assim como no dos demais Jê setentrionais, no caso dos Ràmkôkamẽkra/Canela, não podemos falar em organização matrilinear por não haver nenhuma linearidade relacionada a um grupo de filiação de pessoas. Entretanto, os dados levantados num primeiro trabalho de campo apontam para um tipo de filiação paralela ligada aos povos que compõem os atuais Ràmkôkamẽkra/ Canela. Assim, os filhos se filiam ao povo do pai enquanto as filhas são consideradas pertencentes ao povo de origem da mãe.

Ao que tudo indica, essa parece ser uma forma de demarcar claramente uma identificação dos descendentes dos povos que compuseram os atuais Ràmkôkamẽkra/ Canela e tal identifıcação não é suprimida com a passagem do tempo sendo, ao contrário, mantida exatamente por esse sistema de filiação. 0 principal momento de explicitação dessa característica e de descoberta por parte daqueles que ainda não investigaram suas filiações, se dá durante o ritual do Pep-cahàc. Crocker já havia chamado a atenção para essa característica do sistema de parentesco Ràmkôkamẽkra/Canela ainda nos anos 1970, em artigo apresentado ao Congresso de Americanistas (CROCKER, 1977, p. 261) e voltou a mencioná-la, superficialmente, em sua monografia (CROCKER, 1990, p. 208), argumentando apenas que Nimuendajú considerava que nos Timbira Orientais o pertencimento tribal masculino era transmitido de pai para filho. Nimuendajú (1946, p. 217) referia-se à transmissão do papel de Tamhàc, como chefe-honorário. Mas ele não se referiu a como se dava a transmissão do pertencimento feminino. Crocker (2009) tratou, também de forma rápida, dessa questão ao mencionar os vínculos em volta do círculo das casas (entre os segmentos residenciais mantidos por linhas femininas) e os vínculos através do círculo de casas da aldeia.

Nas sociedades Timbira, o termo referente a "pai" (inxũ) é atribuído a todos os indivíduos que podem manter relações sexuais com a genitora de uma pessoa. Nesse caso, todos os irmãos do "pai”, são con- 
siderados "pai", porque são sexualmente viáveis, assim como todos os homens que possuem o mesmo nome do marido da genitora são chamados de "pai”. No entanto, para os Ràmkôkamẽkra, o princípio da filiação paralela minimiza esta característica e maximiza a paternidade tida como "real".

Um outro momento enfático no Pepcahàc, que trata da atual composição desses povos, são os ensaios da separação dos diferentes povos que compõem os Ràmkôkamekra/Canela. Esses ensaios acontecem por diversas vezes antes da finalização do Pep-cahàc, como uma forma de atualizar o censo dos povos e dos Tamhàc. Durante o censo dos Tamhàc ${ }^{5}$, é feita uma lista com todos esses chefes honorários de cada um desses povos. E cada um deles renova os seus compromissos enquanto chefe honorário. Essa renovação se dá através da oferta de comida, por parte das mães ou mulheres desses chefes honorários, aos membros dos povos ali representados.

Os povos vão procurando os seus Tamhàc para saber se ainda estão por lá em suas casas, com todo o cuidado, para que outro povo não "tome" o seu chefe. Durante essas visitas, o Tamhàc tem a obrigação de dar alimentos ao povo que representa. Em seguida, dirige-se para o pátio para que estes alimentos sejam distribuidos. Cada um dos povos se reúne em grupo. Caso o Tamhàc tenha falecido, lá mesmo o filho dele é escolhido. Mas também eles podem escolher, numa determinada casa, alguém de um povo do qual eles estejam precisando. Quanto mais Tamhàc, mais comida a ser distribuida para o seu povo. Os mẽmoltũmré cresceram bastante, segundo informações dos membros desse povo: atualmente eles possuem cerca de 50 chefes honorários ${ }^{6}$. As mães desses chefes se sentem na obrigação de dar bastante comida. Quanto maior for a oferta de comida, mais o povo vai gostar daquele Tamhàc por suas qualidades generosas. Numa mesma família, filhos de uma mesma mãe podem ser escolhidos por povos diferentes para serem chefes de nações diferentes.

Nesse ensaio sobre a separação dos povos, todos os homens são reunidos no pátio para reconhecimento e separação dos povos aos quais pertencem os Ràmkôkamẽkra /Canela. Os que ainda não sabem qual é o seu povo de origem passam a saber naquele momento e a se reconhecer enquanto tal. Este reconhecimento inicial tem como uma de suas principais finalidades a regulação e regularização do cerimonial dos Tamhàc (chefes honorários), pois após o reconhecimento de cada um dos povos e do que eles chamam do "censo populacional por povo", o passo seguinte é identificar os Tamhàc de cada povo e realizar reconhecimentos e substituições, caso seja necessário.

Após o último ensaio e com a lista de chefes honorários pronta, os povos se espalham e vão à procura de almécega, pena, urucum, amendoa de coco babaçu para o dia da pintura de seus chefes. Após conseguirem todos esses materiais, os mesmos são guardados para o dia da pintura do Tamhàc e execução do canto do popoc.

5. Cada povo escolhe ao menos um membro de cada um dos outros povos presentes e o elege como Tamhàc. Assim, cada povo pode ter ao menos treze Tamhàc (um de cada povo), que serão os chefes honorários do povo que o elegeu.

6. Nimuedanjú (1946) observou a presença de 34 Tamhàc em 1931. 


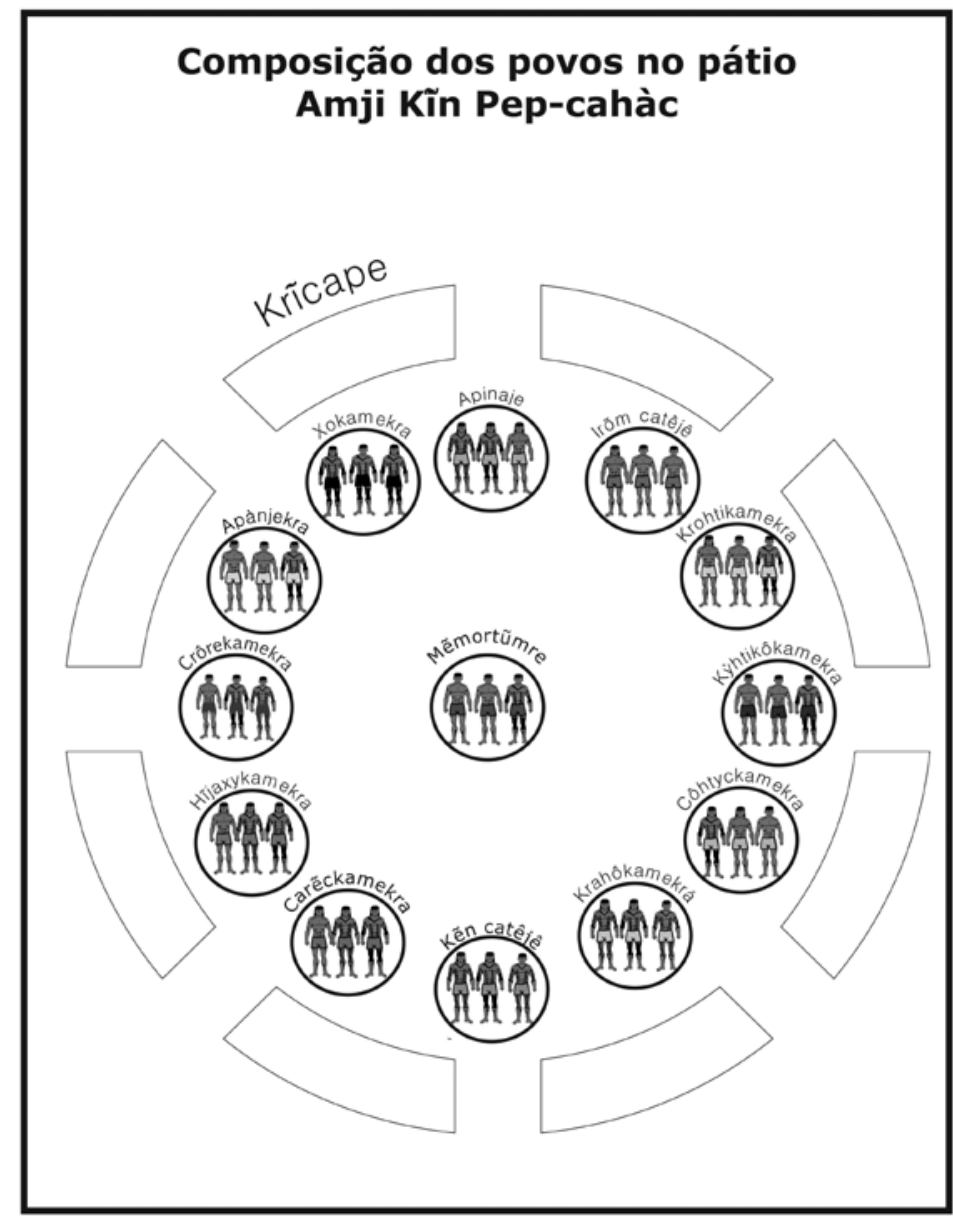

Fonte: Soares/2015.

0 ensaio da separação dos povos no pátio é feito por várias vezes até o momento oficial da separação, que acontece durante a finalização do amji kĩn Pep-cahàc. 0 referido censo, tanto de povos quanto de Tamhàc, aponta para uma composição dos povos da aldeia, atualmente treze povos diferentes, como mostra a Figura $2^{7}$.
Nimuendajú (1946) relata que observou, no Pep-cahàc de 1931, todos os homens se reunirem no pátio onde formaram quatro grupos que, segundo ele, contribuiam para população da aldeia naquela época. Entre esses constavam os Ca'kamekra; Kare'kateje, Krõ'rekamekra e os Ramkõ’kamekra estes últimos ocupando o centro do pátio,

7. Os dados aqui apresentados na elaboração desta figura são originários da tese de doutorado da coautora. Foram coletados a partir do trabalho de campo realizado nos anos de 2013 e 2014 . 
e numericamente predominantes. Nimuendajú também afirma que anteriormente haviam ainda representantes dos Apànjêkra e dos Hoti (Apinaje), cujos descendendes, naquele período, não viviam mais na aldeia; e relata que os três povos que compunham com os Ràmkôkamẽkra, estavam dispostos na beira do pátio de acordo com a direção de onde os seus antepassados emigraram.

Ao estudar os cantos do ritual do Pepcahàc, assim como outros sistemas cancio- nais existentes no universo músico-ritual dos Ràmkôkamẽkra/Canela (Soares/2015), verificamos que os cantos também são constituídos por cantos dos diferentes povos que os compõem, mas também daqueles com os quais mantem relações atuais, como é o caso dos Krĩkati, dos Krahô, dos Pyhcop catiji e dos demais povos Timbira que estabelecem relações, sejam elas de parentesco, rituais, xamânicas entre outras (GIRALDIN; SOARES/2017).

\section{Quadro 1 - Etnônimos Canela}

$\begin{array}{ll}\text { Etnônimos } & \text { Tradução dos termos } \\ \text { Mẽmõltũmre } & \text { Os verdadeiros, os originais } \\ \text { Apànjekra } & \text { Filhos da Piranha } \\ \text { Côhtyckamẽkra } & \text { Filhos da Água preta } \\ \text { Xokamẽkra } & \text { Filhos da Raposa } \\ \text { Krohtikamẽkra } & \text { Filhos da Mucura } \\ \text { Irõm Catêjê/Irõmkamẽkra } & \text { Filhos da Mata } \\ \text { Kẽn Catêjê } & \text { Filhos da Serra } \\ \text { Carẽckamẽkra } & \text { Filhos do Barro } \\ \text { Crôrekamẽkra } & \text { Filhos do Caititu } \\ \text { Kýhtikôkamekra } & \text { Filhos do Cedro } \\ \text { Krahôkamẽkra } & \text { Filhos dos Krahô } \\ \text { Apinaje } & \text { Filhoas dos Apinaje } \\ \text { Hĩjaxykamẽkra } & \text { Filhos do Mateiro }\end{array}$

Fonte: Elaborado por Lígia Raquel Rodrigues Soares.

Diante desse contexto, ficavam sempre as perguntas: de onde surgiu esse nome Ràmkôkamẽkra? Por que os atuais Ràmkôkamẽkra/Canela não se reconhecem como Ràmkôkamẽkra? Por que esses povos assumem o nome Ràmkôkamẽkra/Canela? Por que durante as pesquisas de Nimuendajú os Mẽmõltũmre não são relatados em sua etnografia? 


\section{Os Gavião Pyhcop catiji e outros nomes}

Os Gavião Pyhcop catiji ${ }^{8}$ vivem na parte sudoeste do estado do Maranhão, na microrregião de Imperatriz. A Terra Indígena Governador (TIG) foi demarcada em 1978 e compreende um espaço de 41. 644 hectares, localizada no município de Amarante do Maranhão. Os Gavião vivem hoje em 11 aldeias $^{9}$, resultado de um processo de dispersão recente, iniciado em 2010. 0 que se pode afırmar é que hoje os Gavião Pyhcop catiji são uma "mistura”, como dizem os velhos, de grupos locais que já estavam na região de mata do Rio Pindaré e daqueles que migraram da Bacia do Mearim e da Bacia do Rio Gurupi, principalmente pelo Rio Grajaú, Rio Gurupi e Rio Tocantins para a região. Estes "subgrupos”, ou "grupos de nominação” ou etnônimos, como vamos chamá-los, são conjuntos de nomes com termos que designam partes de um grupo. São formados, frequentemente, pela composição de nomes de animais, plantas e outras qualidades acrescidos de um sufixo.

Quando Nimuendajú esteve com os Gavião Pyhcop catiji em 1929, dividiu os Timbira orientais em um conjunto de 15 grupos através de critérios linguísticos e da localização em comum. Desde então, sabemos muito pouco da relação que estabeleciam esses grupos no passado e das formas que assumiram historicamente hoje.

Segundo Nimuendajú (1944), no início do século XX os Gavião estavam divididos em duas aldeias: São Felix e Recurso. Mas os dados de campo criaram certa dúvida sobre a existência de apenas duas aldeias nesse período, ou indicam uma grande dispersão nos anos seguintes, o que parece pouco provável. Quando os moradores mais velhos são questionados sobre o nome Gavião nas aldeias na TI Governador, uma série de topônimos foram localizando outras aldeias dentro desse território, aldeias que não temos como precisar a data em que foram ocupadas ou quando foram abandonadas, mas que, pelas narrativas, existiam nas primeiras décadas de 1900. Essa suspeita se comprovou quando tivemos contato com as professores Diana Bandeira e Marcelia Sansão, que trabalhavam na cartografia da TI Governador fazendo o levantamento dos nomes indígenas das aldeias que já existiram no território $^{10}$. Elaboramos juntos o quadro a seguir.

8. Optei em utilizar a grafia desenvolvida pelos professores indígenas gavião, que resulta de um estudo onde corrigiram o trabalho de missionários da New Tribes, que escreveram uma primeira versão da "língua Gavião e Krikati”. As correções se deram no sentido de adaptar a escrita, baseada na pronúncia do povo Krikati, a pronúncia gavião das palavras.

9. As aldeias são: Aldeia Governador, Aldeia Riachinho, Aldeia Nova, Aldeia Monte Alegre, Aldeia Bom Jardim, Aldeia Rubiácea, Aldeia Canto Bom, Aldeia Dois Irmãos, Aldeia Bom Jesus, Aldeia Água Viva, Aldeia Novo Marajá.

10. As professoras cursam Licenciatura Intercultural Indígena na Universidade Federal de Goiás. Na ocasião, trabalhavam nesse levantamento cartográfico para ser apresentado como um trabalho do curso. 


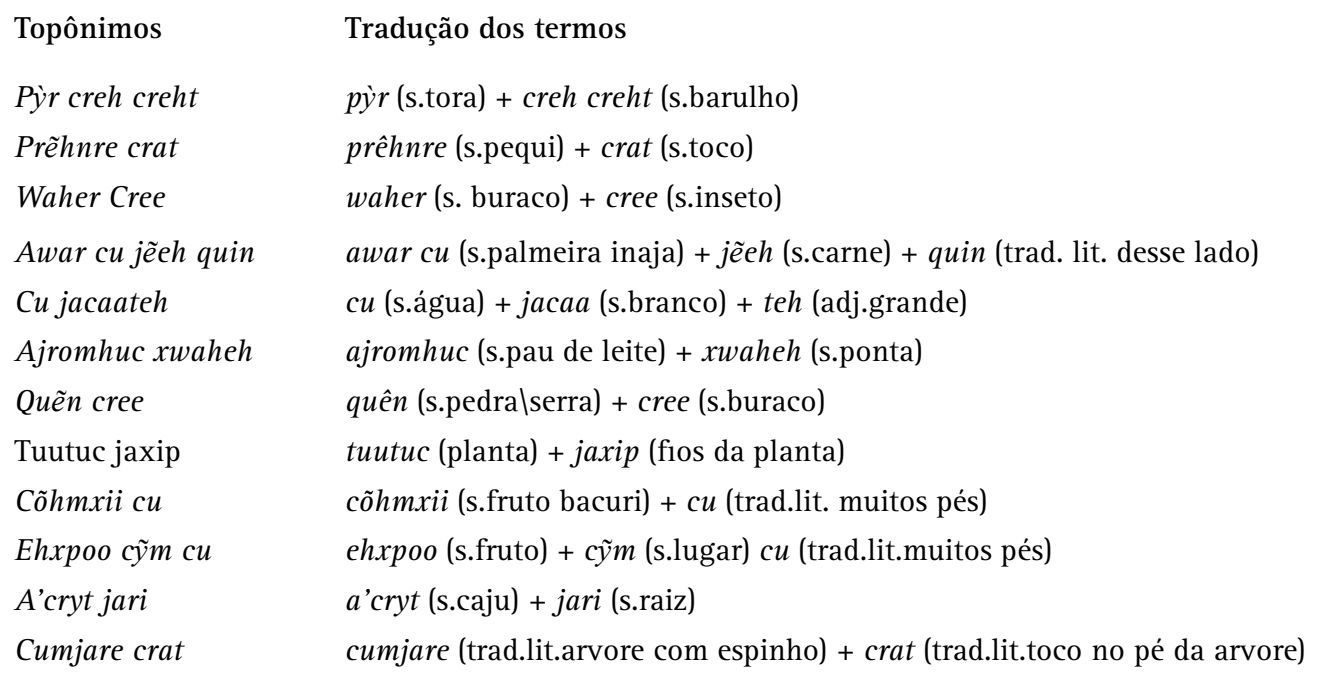

Fonte: Elaborado por Diana Bandeira, Roberto Gavião, Marcelia Sansão e Maycon Melo

Foi através dos topônimos que localizam as aldeias dentro e fora da TI Governador que tivemos acesso aos "subgrupos", ou "grupos de denominação", ou ainda, "etnônimos", como vamos chamá-los, em uso pelos Gavião. 0 "nome antigo" de um lugar, quando era pronunciado, abria o campo semântico das conversas e trazia consigo o "nome antigo" dos povos que viviam nestes lugares. Ou seja, povos que se reconheciam por etnônimos diferentes e com origens diferentes, os quais viviam distribuídos naquelas 12 aldeias que identificamos por meio dos topônimos. Hoje, como dissemos, os Gavião são uma "mistura" de povos, mas em alguns momentos, como pudemos observar, essa "mistura" decanta e o que vem à tona são elementos bem diferenciados entre estes grupos que se reconhecem por diferentes etnônimos, só se autoafirmando Gavião Pyhcop catiji à frente dos cohpẽ (não-indígena).
Em dois contextos diferentes, pudemos observar o uso destes etnônimos e como estes indicavam formas de socialidade entre grupos, entre povos diferentes: o primeiro contexto relacionado à dispersão e à contração das aldeias Gavião a partir dos anos 2000, o segundo envolve uma acusação de feitiçaria que teria iniciado uma série de mortes envolvendo os Cree pym catiji e os Gavião.

0 principal contexto de uso destes etnônimos está naquilo que se refere aos deslocamentos dos grupos de uma aldeia para outra, motivados por conflitos internos. Nas narrativas sobre a origem do povo Gavião, sobre o nome dos povos que viviam nessa região ou daqueles que vieram de outro lugar, é visível a relevância das migrações da Bacia do Mearim em direção ao leste do Rio Pindaré. 
Figura 3 - Dispersão e reagrupamento das aldeias Gavião Pyhcop catiji.

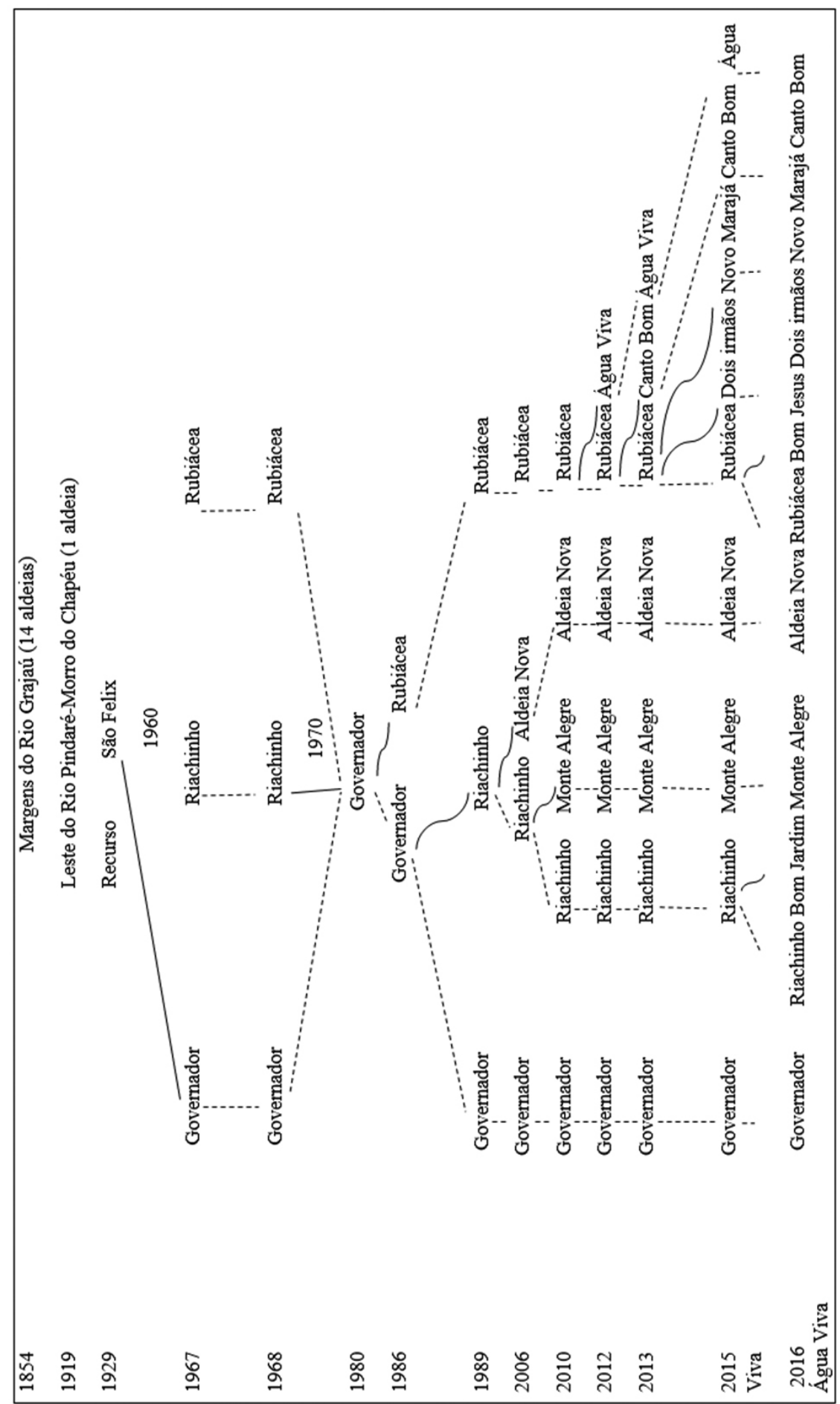

Fonte: Elaborado por Maycon Melo. 
0 sentido da ocupação que resultou na divisão das aldeias, com origem na região do Rio Grajaú até a bacia do Rio Gurupi, é o mesmo do mito "gavião de Patjapi” (M1) que narra a origem da divisão dos povos Timbira e outros Jê.

Os índios fugiam do Rio de Janeiro das investidas de Pedro Alvares Cabral. Muitos ficaram lá, outros vieram até São Luís. Fizeram outras aldeias que novamente foram atacadas. Continuaram fugindo. Fizeram uma aldeia do lado de cá do rio onde hoje é Grajaú [lado oriental]. Enquanto se banhavam e bebiam em uma pequena lagoa, viram um grande peixe cascudo ${ }^{11}$. Por onde ele descia a água vinha descendo com ele. Essa água deu origem ao rio Grajaú. Fizeram uma aldeia grande nesse lugar. Para visitar os parentes do outro lado do pátio gastavam um dia de viagem. Patjapi achou que aquilo estava errado. Chamou todos no pátio e começou a separar os povos indicando a direção e a fala [língua] que cada um deveria assumir. Assim foi dizendo: Cy tyhcre cati ji, Cree pym cati ji, Pyhcop cati ji, Rõo cy cati ji, Cohcuj re catiji, Pji hỹre cati ji [Krikati] Mỹy ca mecrare [Krahõ] Caiapo cati ji [Kayapó], Pyh txiteh [Xerente], Gavião do Para catiji, Wacu con, Gurupi cati ji, Caraja cati ji (Damásio Gavião, Aldeia Rubiácea, 2015).

No entanto, nas narrativas que ouvimos em campo, alguns destes povos são reconhecidos por já estarem na região quando os deslocamentos do Grajaú ocorreram.
Dentre eles estão os Pyhcop catiji ( $p y h$. s. urucu + cop; n.p., v. rastejar, s. lança + cati $j i$;. povo, s.afins), que viviam na antiga Aldeia São Felix.

Ao que parece, desde as primeiras décadas de 1900 já viviam na Aldeia Governador outros povos além dos Pyhcop, como os Pji hỹre catiji (pji:s. terra) e os Rõo cu catiji (Rõo cuu; s. gonga ${ }^{12}$ + cati ji; s. povos. afıns). Rõo cuu, como muitas pessoas me disseram, é como era chamado o grupo que vivia em uma região de cocal próximo ao município de Amarante do Maranhão. Seria um subgrupo dos Krikati, ou como são chamados hoje pelos Gavião, parte dos Põo catiji (põo; s.chapada, s.campo + cati ji; s. povo, s. afins), nome que os Krikati receberam depois que se deslocaram para as terras de Montes Altos, onde vivem hoje. Além dos Roo cu, viviam em Governador também os Xo teh catiji (xo;s. cachorro + teh; adj. grande) + catiji; s. povo-s. afins), que já eram emigrantes da região do Rio Grajaú e, os Gurupi catiji. Os Gurupi quebram o sentido dos deslocamentos antes conhecidos somente pela Bacia do Mearim, no sentido Rio Grajaú abaixo, pois esse grupo teria se deslocado pelo rio Gurupi no sentido rio acima.

Na Aldeia Riachinho viviam outros três povos. 0 pai do cacique Joel, o cacique José Martins, é remanescente dos Cohcujre cati ji (cohcuj; s.macaco + re; adj. pequeno + cati ji; s. povo- s. afins). Na literatura, os Cohcujre são conhecidos como Krẽnhe, que se deslocaram da região do Grajaú fugindo

11. Loricariidae: nome comum aos peixes siluriformes da família Loricariida e, também conhecidos como acari, acari-bodó, bodó, cari, boi-de-guará e uacari. Os loricariídeos são peixes exclusivamente de água doce, tem corpo delgado, placas ósseas e cabeça grande, habitam o fundo dos rios, alimentam-se de lodo e restos orgânicos, são encontrados no rios e lagos da América Central e do Sul.

12. 0 gongo é uma larva de besouro da família dos bruquídeos que se desenvolve dentro do fruto de várias espécies de palmeiras, dentre elas, as mais comuns - o coco babaçu e macaúba. 
de conflitos com os Cohpẽ (branco). 0 outro grupo, que deixou Riachinho na dispersão de 2010 para criar a Aldeia Monte Alegre, é na verdade formado por outros dois grupos.

Maria Helena (Tiire cwyj), liderança feminina da Aldeia Monte Alegre, é filha de pessoas do grupo Rõo cuu catiji quem segundo as narrativas, habitavam a parte norte da TI
Governador, talvez remanescentes do grupo dos Krikati que buscou refúgio na década de 1930 nessa região (LAVE, 1967). 0 outro grupo em Monte Alegre é o da família do cacique Getúlio. Ele e sua família são filhos de Cree pym catiji (cree; v.cantar, s.ovos + pym; v.cair + cati ji; s. povo, s.afins) que já nasceram na TI Governador.

\section{Quadro 3 - Etnônimos em uso pelos Gavião}

\begin{tabular}{|c|c|}
\hline Etnônimo & Tradução dos termos \\
\hline Pyh cop catiji (Gavião Pukbjê) & $\begin{array}{l}\text { Pyh (s.urucu) + cop (n.p. - v. rastejar - s. lança) + cati ji (s. } \\
\text { povo - s.afins) }\end{array}$ \\
\hline Cree pym catiji (Krepumkatejê) & Cree (v.cantar - s.ovos) + pym (v.cair) + cati ji (povo-afins) \\
\hline Rõo cu catiji (subgrupo Krikati) & Rõo cuu (s. gonga) + catiji (s. povo- s. afins) \\
\hline Xo teh catiji & Xo (s. cachorro) teh (adj. grande) + catiji (s. povo- s. afıns) \\
\hline Cu'tyhcre catiji & Cu (s.água) + tyhcre(adj.preto) + catiji (s.povo-s. afıns) \\
\hline Cohcujre catiji (Krenyê) & $\begin{array}{l}\text { Cohcuj (s.macaco) + re(adj.pequeno) + catiji (s. povo- s. } \\
\text { afins) }\end{array}$ \\
\hline Pji hỹre catiji & Pji (s. terra,chão) + catiji (s. povo- s. afıns) \\
\hline Põo catiji (subgrupo Krikati) & Põo (s.floresta) + catiji (s. povo- s. afıns) \\
\hline Gurupi catiji & Gurupi (Rio Gurupi) \\
\hline $\begin{array}{l}\text { Cyj craare (Ràmkôkamekra/Canela[Ald. } \\
\text { Ponto]) }\end{array}$ & Cyj (s. machado) + craare (s.filho,filhote) \\
\hline Mỹy craare (Krahô) & Mỹy (s.ema) + craare (s.filho,filhote) \\
\hline
\end{tabular}

Fonte: Elaborado por Roberto Gavião e Maycon Melo.

Os Cree pym são conhecidos na literatura como Krepumkatejê. As narrativas indicam que fugiram da região do Grajaú, chegando primeiro nas aldeias Tentehar/ Guajajara - no norte da TI Governador, onde se casaram com Tentehar/Guajajara e com citadinos, além daqueles que se estabeleceram na Aldeia Rubiácea. Anos depois, o cacique de Rubiácea, Damásio (Wajpe), teria ido junto com o chefe do PIN Governador, José Pedro, buscar o restante do grupo que ainda vivia próximo a Grajaú. Em 2016 a morte de um dos filhos das mulheres remanescentes deste grupo Cree pym, supostamente por um Gavião, motivou cerca de 40 pessoas a abandonarem a Aldeia Rubiácea e retornarem a TI Geralda Toco Preto, onde vivem atualmente os Krepumkatejê. Os jovens que já nasceram na TI Governador não se adaptaram, retornaram e construíram a Aldeia Bom Jesus, onde vivem atualmente.

Em relação ao grupo da Aldeia Rubiácea, a maior parte dele, assim como o cacique Damásio (Wajpe), vieram da antiga Aldeia Rubiácea, que ficava próximo da 
Aldeia Borges, na parte norte da TI Governador. A maior parte desse grupo da Rubiácea é remanescente dos $\mathrm{Cu}$ tyhcre catiji (cu; água+ tyhcre; adj. preto + cati ji; s. povo,s. afins) que viviam na região do Rio GrajaúMA, provavelmente próximo a Alto Alegre do Maranhão-MA.

Quando Nimuendajú (1944) esteve com os Gavião, em 1929, ele conta ter encontrado sobreviventes do povo "Kotukrekateye". Também menciona como eles habitaram o Alto do Grajaú e teriam se envolvido na revolta dos Tentehar/Guajajara aos padres capuchinos em Alto Alegre do Maranhão ${ }^{13}$.

De acordo com as narrativas em português que descrevem o que levou a cada uma das cisões, principalmente a partir dos anos 2000, os conflitos internos estavam relacionados à disputa pelo controle dos bens e benesses que as políticas públicas supostamente trazem para dentro das aldeias, como carros, motos, cargos, dinheiro. As discussões iniciavam-se entre a família do cacique, acusada de favorecer a si própria, e aquelas que se sentiam prejudicadas. Quando os ânimos realmente se exaltavam e todos passavam a temer o pior, ou seja, conflitos que pudessem levar à morte, decidiam se separar.

Todavia, depois que tive acesso aos etnônimos, pude observar como nessas dispersões das aldeias não se tratava apenas de famílias nucleares ou grupos domésticos que se deslo- cavam de um lugar para o outro. Compreendi serem grupos, por vezes todo o grupo, que se identificam com o mesmo etnônimo e que possuem narrativas de origem em comum. Pouco a pouco, depois destas dispersões, criaram-se aldeias que se tornaram, até certo ponto, células autônomas dentro da TI Governador que passaram a reivindicar o que consideram que lhes é de direito; mesmo que isso criasse conflitos com os outros parentes.

0 outro contexto de uso destes etnônimos se refere a uma acusação de feitiçaria que teria iniciado uma série de mortes envolvendo os Cree pym catiji e os Gavião dentro da TI Governador. Uso o nome Gavião, não qualquer outro etnônimo especificamente, como Cree pym, porque foi assim que me descreveram as mortes, "Cree pym e Gavião se matando". Ao que parece, foram quatro mortes, duas delas ocorreram em 2016.

Enquanto caçava no fim do dia próximo à aldeia um homem Gavião foi baleado na cabeça por um Cree pym, que alegou ter confundido o colega de caça com um caititu ${ }^{14}$. Das inúmeras versões sobre o fato acontecido, duas possibilidades se colocaram para os moradores da Aldeia Governador: acidente ou assassinato. A segunda morte ocorreu dois meses depois na Aldeia Rubiácea. As placas solares da escola da aldeia foram roubadas e os ladrões, reconhecidos. Um grupo dos Gavião foi exigir a devolução das placas

13. Estes últimos estariam revoltados pelos maus tratos que as crianças nas escolas dos padres recebiam. Em duas narrativas que ouvi sobre o caso, narradas por mulheres autoidentificadas netas dos $\mathrm{Cu}$ tyhcre, no dia do conflito com os padres, um dos homens $\mathrm{Cu}$ tyhcre teria se envolvido e levado consigo o dinheiro saqueado dos padres. Quando retornou à cidade para comprar gado e farinha, as moedas foram reconhecidas pelos comerciantes, que deduziram que estavam envolvidos com as mortes. Entregaram a ele comida envenenada. A maior parte da aldeia morreu. Com uma grande baixa populacional e acuados pelos cohpẽ, o grupo começou um longo deslocamento até a região de Amarante do Maranhão. Pelo caminho, muitos foram morrendo, as crianças eram encontradas sozinhas ao lado dos corpos, algumas foram levadas e criadas pelos cohpẽ nas cidades por onde passavam.

14. Pecari tajacu 
e o acusado era filho de mãe Cree pym e pai cohpẽ. Logo uma confusão generalizada deu início a uma briga de facão, homens e mulheres se cortaram. 0 acusado foi atingido com um caibro de madeira na cabeça e morreu. Depois disso, em torno de 40 pessoas das famílias Cree pym deixaram a Aldeia Rubiácea e retornaram a TI Geralda Toco Preto, onde vivem seus parentes.

Antes de presenciar esses casos, eu ouvira narrativas sobre os encontros dos Gavião e Cree pym que resultavam em grande número de mortes. Durante as caravanas de gado que vinham de Goiás e passavam por Carolina-MA, cruzando as terras dos Krahô, Gavião, Krĩkati, muito homens seguiam os peões e quando cruzavam certos territórios os conflitos eram inevitáveis, como quando os Gavião cruzavam as terras dos Cree pym na região do Rio Grajaú. Levado por essas narrativas, associei os nomes às mortes e perguntei a pessoas de idade, e que estariam supostamente relacionadas com as mortes, se haveria algo a mais nessa história de mortes entre Gavião e Cree pym. 0 conflito, digamos, de ordem recente, mas de causa antiga, teria se iniciado com uma suposta acusação de feitiçaria que terminou em morte de um Gavião. Anos depois um consanguíneo do morto teria assassinado uma mulher Cree pym, também a acusando de feitiçaria. Nos dois casos mais recentes, ninguém mencionou feitiçaria, mas sim vingança. Depois da morte em 2016, na Aldeia Governador, ouvi muitos dizendo que não permitiriam que matassem seus parentes assim, que reagiriam se o assassino Cree pym retornasse à aldeia. As mortes narradas mostram que não necessariamente a vingança se dirige apenas ao assassino, qualquer outro membro da família pode ser morto no lugar dele e as mortes ficam adormecidas até outro infortúnio acionar esse mecanismo.
De forma menos velada do que parece, a feitiçaria é uma realidade entre os Gavião e como ocorre com outros grupos da Amazônia, parece ocupar um lugar no sistema político (COELHO DE SOUZA, 2001). Mesmo as acusações de feitiçaria tendo um uso restrito, como os etnônimos também o têm, a feitiçaria aparece como um sistema de abertura destes grupos ao exterior, algo importante no processo de constante reconstituição desse sistema de fronteiras fluídas que em determinados momentos está baseado em alianças e, em outros, em conflitos. Nesse contexto, os Gavião, que como vimos, são formados por vários grupos locais, usam de forma especifica o etnônimo Cree pym para se referir àqueles que mataram ou foram mortos nessa história. Mesmo falando uma língua com muitas semelhanças, o termo usado nesse contexto marca um certo distanciamento entre os grupos, colocando-os ora como aliados - já que Cree pym e Gavião têm há muitos anos mantido relações de casamento - ora como inimigos - o que parece atualizar os conflitos do passado.

0 caso dos conflitos envolvendo os Gavião e Cree pym, assim como os que envolvem outros grupos, é sintomático no que se refere às colocações de Azanha sobre os sufıxos catejê e (ca)mekra. Azanha (1980) afirma que entre aqueles que se designam mutuamente usando o catejê não há registros de guerras, mas a história entre os Cree pym e Gavião, ou melhor, os grupos que viviam próximo das florestas do Pindaré, nos alertam que há sim conflitos que levam à morte entre ambos. Como há conflitos entre os Gavião e grupos de língua Tupi, como os Tentehar/Guajajara, os Prỹyjẽh (prỹy (s. caminho) + jẽh (s. carne, s. espinho).

De forma geral, o sufixo catiji é usado como pluralizador e se refere a um grupo 
que compartilha características especificas, como me pa'heeh catiji (os caciques), mas também é usado para se referir a coletivos em português, como professor catiji, jogador catiji. Além desse sentido, entre os Gavião o ji é também fragmento dos termos de parentesco entre afıns, como ehmpÿnji (WZ), êhjpŷnji (BW, WM), pyyjquitji (WF), ẽhjxwyji (SW), pẽhjõoji (ZH, DH), o que sugere a possibilidade de aparentamento ao sufixo, além do sentido pluralizador. No caso do sufixo (ca)mekra, seguindo com Azanha (1984), ele marca uma diferença quanto à origem e as relações entre os grupos designados que nesta forma estariam baseadas no estado de guerra permanente entre eles.

Este estado de guerra está presente nas narrativas envolvendo os Gavião e os Cyj craare [Canela. Ald Escalvado] (cyj; s. machado + craare; s. filho, filhote) e Mỹy craare [Krahô] (mỹy; s.ema + craare; s. filho, filhote). Os Gavião e esses dois grupos praticavam ataques uns aos outros em busca de um machado semilunar de pedra (cỳxre), usado como poderoso instrumento de guerra entre os povos Timbira, quando não dispunham de metal. Expedições eram realizadas, territórios extensos eram percorridos para matar inimigos, se possível, mas principalmente para roubar exemplares desse machado. Contaram-me que o exemplar da machadinha que restou está no Centro de Pesquisa de História Natural e Arqueologia do Maranhão. Foi em expedições de guerra contra os Ràmkôkamẽkra/Canela que os Gavião conseguiram roubar as machadinhas. Muitos anos depois, quando já não havia mais as guerras, um Ràmkôkamẽkra/Canela na Aldeia Governador teria roubado a machadinha e levado novamente até a antiga Aldeia do Ponto (TI Kanela). Em posse dos Ràmkôkamẽkra/Canela teria sido roubada por um Krahô e vendida ao Museu. João Damasceno, coordenador do Setor de Etnologia e Museologia do Centro de Pesquisa de História Natural e Arqueologia do Maranhão, que possui experiência com os povos indígenas do Maranhão, contou-me pessoalmente que a machadinha não foi vendida. Ela foi recuperada, pela Polícia Federal, de um italiano que tentara ilegalmente embarcar com ela. Ele foi obrigado a deixá-la no Centro de Pesquisa, em regime de comodato, o que, na verdade, não muda os sentidos das narrativas Gavião sobre a machadinha e os Cyj craare. Os dois sufixos, catiji e craare, são cotidianamente usados em conversas, hoje são muitos os casamentos entre povos que se identificam tanto com um como com outro termo.

0 uso dos etnônimos nas narrativas sobre as dispersões e reagrupamentos das aldeias Gavião e nas acusações de feitiçaria aparece como uma forma de marcar fronteiras entre grupos. Podemos dizer que os etnônimos gavião são usados para se referir a si mesmo, a uma família, a residentes de uma mesma aldeia, a povos vizinhos e a inimigos do passado e do presente. Como afirmou Arisi (2012) sobre os etnônimos pano, os etnônimos parecem pertencer a um estoque de etnônimos, são marcadores internos e externos, nomeiam povos do entorno e os netos e bisnetos destes povos que hoje vivem "misturados" ${ }^{15}$. Segundo as

15. Los etnónimos son ese stock disponible en diversos niveles, sirven para arreglos "alternativos" de las categorías sociales, son términos que traen en si cierto bagaje histórico que denuncia su origen en eventos pasados para designar marcadores que van más allá de términos sociológicos fijos como "nosotros", "nuestros otros", “otros", "muy otros”. Los etnónimos son adaptables a muy diferentes contextos, son más flexibles que categorías de identidad, no son fijos, son alternativos, cambiantes y múltiples. (ARISI, 2012, p. 33). 
narrativas de "origem", antes as fronteiras entre estes etnônimos eram mais claras, por mais que tivessem semelhanças linguísticas - o que sempre é destacado -, os grupos vinham de lugares diferentes, ocupavam lugares diferentes. Tinham características físicas diferentes, podiam ser aliados ou inimigos, dependendo de questões que foram se mostrando contingenciais.

Talvez por isso os etnônimos sejam tão flexíveis e cambiantes, porque estão constantemente, mesmo que com menos frequência, sendo colocados à prova através das formas de socialidade nas quais ganham sentido. Os etnônimos gavião são múltiplos, mas conhecer os nomes e os contextos de uso indicam para além de múltiplos, indicam como, principalmente, contraditórios e complementares. 0 contato com os cohpẽ tratou de, ao longo das décadas, colocar os netos e bisnetos remanescentes dos grupos locais Gavião sob o mesmo nome Pyhcop, Gavião Pyhcop catiji. "Hoje está tudo misturado", mas como vimos, nem tudo.

\section{Considerações finais}

Ao longo das apresentações dos estudos de caso, foi possível perceber a relação intrínseca entre etnônimos e topônimos. Os nomes dos povos estão associados a regiões, lugares, habitats, animais, plantas características de uma determinada região. Esse ponto pode ser percebido nos dois estudos de caso explorados no texto. Mas, até que ponto esses nomes são autorreferência desses povos? $\mathrm{Ou}$, são nomes dados por inimigos e posteriormente incorporados? Ou, nomes dados pelos colonizadores? E como esses etnônimos, que sempre nos levam aos topônimos, foram incorporados pelos pesquisadores e posteriormente por esses povos?
Este texto tem como ponto de reflexão os etnônimos, mas a nossa intenção também foi fazer com que outros pontos dessa reflexão possam ser retomados, tratados e rediscutidos pelos novos pesquisadores Timbira à luz da atualidade e da dinâmica cultural. Esperamos que este texto sirva como uma provocação aos pesquisadores indígenas e não-indígenas, no sentido de explorar temas que aparentemente se dão por pesquisados, mas que ainda necessitam de um olhar mais atento ou de novos olhares, como forma de trazer mais contribuições para o entendimento do tema aqui discutido e também de outros temas que merecem mais atenção dos pesquisadores Timbira.

\section{Referências}

ARISI, B. La No-Frontera Pano: etnónimos como categorías alternativas y múltiples entre Matis y Korubo. Tipiti: Journal of the Society for the Anthropology of Lowland South America, v. 10, issue 2, p.19-36, 2012.

AZANHA, G. A forma Timbira: estrutura e resistência. 1984. 81f. Dissertação (Mestrado em Antropologia Social) - FFLCH, Universidade de São Paulo, São Paulo, 1984.

CALÁVIA SÁEZ, 0. Nawa, Inawa. Revista Ilha, Florianopólis, v. 4, n.1, p. 35-57, jul. 2002.

Nomes, pronomes e categorias: repensando os "subgrupos" numa etnologia Pós-Social. Revista Antropologia em Primeira Mão, v.138, p. 6-17, 2013.

CROCKER, W. H. The Canela (Eastern Timbira): an ethnographic introduction. Smithsonian contributions to anthropology, n. 33, Washington: D.C. 1990.

Os Canelas: parentesco, ritual e sexo em uma tribo da Chapada Maranhense. Série Monografias, Rio de Janeiro, Museu do Índio/FUNAI, 2009. 
DEMARCHI, A.; MORAIS, 0. R. Conexões Jê: Redes de relações indígenas no Brasil Central. 39 ENCONTRO DA ANPOCS, 2015.

GIRALDIN, 0.; SOARES, L. R. R - "Você quer mesmo escutar e cantar increr cahàc-re?” As classificações dos cantos de cà (pátio) para os Ràmkôkamẽkra/Canela. IN: Saberes e Ciència Plural: diálogos e interculturalidade em Antropologia / Deise Lucy Oliveira Montardo, Márcia Regina Calderipe Farias Rufıno (organização). Florianópolis: Editora da UFSC, 2017.

GIRALDIN, O. AXPÊN PYRÀK: história, cosmologia, onomástica e amizade formal Apinaje. 2000. $296 f$. Tese. (Doutorado em Antropologia Social) - IFCH, Universidade Estadual de Campinas, Campinas, 2000.

HYWY WATO Futebol Clube. Direção: Maycon Melo. Manaus. Núcleo de Antropologia Visual e Estudos da Imagem|PPGAS, Universidade Federal de Santa Catarina, 2011. (20min). NTSC. Disponível em: <https://vimeo.com/39008769>. Acesso em: 16 jun. 2017.

LADEIRA, M. E. A troca de nomes e a troca de cônjuges: uma contribuição ao estudo do parentesco Timbira. 1982a. Dissertação (Mestrado em Antropologia Social) - FFLCH, Universidade de São Paulo, São Paulo, 1982a.

Uma aldeia Timbira. In: NOVAES, S. C. (Org): Habitações indígenas, São Paulo: Nobel, 1982b, $28 \mathrm{p}$.

MELO, M.; RIAL, C. 0 futebol das mulheres Sateré -Mawé. SIMPÓSIO DE FUTEBOL: ESPETÁCULO E CORPORALIDADE, ENCONTROS NO ESPETÁCULO FUTEBOLÍSTICO. Núcleo de Antropologia Visual e Estudos da Imagem/PPGAS, Universidade Federal de Santa Catarina, Florianópolis, 2010.

MELATTI, J. C. 0 sistema social Krahô. Tese. (Doutorado em Antropologia Social) - FFLCH, Universidade de São Paulo, São Paulo, 1970.

Ritos de uma tribo Timbira. São Paulo: Ática, 1978.

NIMUENDAJÚ, C. U. Os Timbira Orientais. Belém do Pará, 16 de julho de 1944, monografia publicada em 1946, post-mortem.
The Eastern Timbira. University of California, Berkeley and Los Angeles, 1946.

OLIVEIRA, A. L. R. Ramkokamekra-Canela: dominação e resistência de um povo Timbira do centro-oeste maranhense. 2002. Dissertação (Mestrado) - IFCH, Universidade Estadual de Campinas, Campinas, 2002.

Messianismo Canela: entre o indigenismo de Estado e as estratégias do desenvolvimento. 2006. Tese (Doutorado em Políticas Públicas) - CCSO, Universidade Federal do Maranhão, São Luís, 2006.

Messianismo Canela: entre o indigenismo de Estado e as estratégias do desenvolvimento. São Luís: EDUFMA, 2011.

RIVIERE, P. Individual and Society in Guiana: a comparative study of Amerindian social organization. Cambridge University Press, 1984.

SILVA JÚNIOR, J. A. Awkhê ressignificado: os movimentos messiânicos Canela. 2006. Monografia (Bacharelado em Ciências Sociais) - Universidade Federal do Maranhão, São Luís, 2006.

SIQUEIRA, J. G. Relatório circunstanciado de revisão de limites da terra indígena Canela/Buriti Velho - MA. Fundação Nacional do Índio - FUNAI, Brasília - DF, fevereiro de 2006.

Soares, L. R. R. Mẽ Amji kĩn e pjê cunẽa: cosmologia e meio ambiente para os Ràmkôkamẽkra/Canela. Dissertação (Mestrado em Ciências do Ambiente) - Programa de Pós-Graduação em Ciências do Ambiente, Universidade Federal do Tocantins, Palmas, 2010.

"Eu sou o gavião e peguei a minha caça”: 0 ritual Pep-cahàc dos Ràmkôkamẽkra/ Canela e seus cantos. Tese (Doutorado em Antropologia Social) - PPAS, Universidade Federal do Amazonas, 2015.

STEWARD, J. H. (Org.). Handbook of South American Indians, v. 3, Washington: Smithsonian Institution, 1948

TAROVA: os cantos da Opy. Direção: Maycon Melo e Viviane Vasconcelos. Núcleo de Antropologia Visual e Estudos da Imagem/PPGAS, Universidade Federal de Santa Catarina, São Francisco do Sul, 2012. (22min). NTSC. 
RESUMO

Desde Nimuendajú (1946) é possível comparar várias características que se repetem ou que muito se aproximam entre os povos Timbira por ele pesquisados. Porém, também desde Nimuendajú, sabemos muito pouco da relação que tais povos mantinham entre si e, principalmente, das formas que assumiram estas relações historicamente. Depois de anos de dispersões e reagrupamentos, podemos dizer que os Ràmkôkamẽkra/Canela e os Gavião Pyhcop catiji se denominam como uma "mistura" de povos diferentes que se autoidentificam com o mesmo etnônimo à frente dos não indígenas (cohpẽ, nos Pyhcop catiji; Cupẽ, nos Ràmkôkamẽkra/Canela). Ainda assim, em momentos rituais ou de conflitos entre si acionam em suas narrativas origens, trajetórias e etnônimos que os diferenciam dessa aparente mistura. Por isso, a proposta do artigo é focalizar os etnônimos atualmente em uso pelos Ràmkôkamẽkra/Canela e Gavião Pyhcop catiji, abordando temas como circulação e apropriação de pessoas e a descrição das redes de relações e formas de socialidade que tais redes sugerem.

\section{PALAVRAS-CHAVE}

Etnônimos. Redes derelação.Ràmkôkamẽkra/ Canela. Gavião Pyhcop catiji.

\section{ABSTRACT}

Since the Nimuendaju's paper (1946) we can compare and think about a lot of ethnographic characteristics that repeat or approach itself among the Timbira people, among whose he had make research. Since Nimuendaju, however, we know very little about the relationship that people establish between them, mostly about the historical relationships. After years of dispersion and shrinkage among that peoples we can say that the Ràmkôkamékra/Canela and Gavião Pyhcop catiji see themselves as a miscellaneous of peoples that identify themselves with the singular ethnonym against the no indigenous (called cohpe, for the Pyhcop catiji; Cupẽ, for the Ràmkôkamẽkra/Canela), but in moments of internal conflicts or in rituals ones, they drive theirs narratives of origin, the path and ethnonym that sets them apart of that apparent mixture. So, this paper target is to focus about the ethnonyms used by Ràmkôkamékra/Canela and Gavião Pyhcop catiji approaching topics like peoples appropriation/circulation and the description of the web of relationships and sociality forms that such web suggests.

\section{KEYWORDS}

Ethnonym. Relationships web. Ràmkôkamẽkra/ Canela. Gavião Pyhcop catiji. 
